\title{
A GIS method for assessment of rock slide tsunami hazard in all Norwegian lakes and reservoirs
}

\author{
B. Romstad ${ }^{1,3, *}$, C. B. Harbitz ${ }^{2,3}$, and U. Domaas ${ }^{2,3}$ \\ ${ }^{1}$ Department of Geoscience, University of Oslo, Norway \\ ${ }^{2}$ Norwegian Geotechnical Institute, Oslo, Norway \\ ${ }^{3}$ International Centre for Geohazards (ICG), Oslo, Norway \\ *now at: CICERO Center for International Climate and Environmental Research, Oslo, Norway
}

Received: 4 November 2008 - Revised: 13 February 2009 - Accepted: 19 February 2009 - Published: 17 March 2009

\begin{abstract}
An evaluation of rock slide tsunami hazard is applied to all Norwegian lakes larger than $0.1 \mathrm{~km}^{2}$ based on their topographical setting. The analysis results in a topographic rock slide potential score that indicates the relative hazard in each lake. Even though the score value each lake receives should be interpreted with caution, the distribution of score values shows that we are able to make a clear distinction between lakes with a high vs. lakes with a low hazard. The results also show a clustering of threatened lakes in parts of Western Norway as well as some locations in Northern Norway. This makes the results useful as a tool for focusing further studies on regions or specific lakes that received high scores. The results also show how the method may be used for more detailed analysis of a given lake (or fjord). Maps can be produced that may serve as a guide when carrying out field campaigns or when designing scenarios for numerical simulations of tsunamis in the lake. It should be emphasised that the rock slide potential reported for each lake is based on the topographical setting alone and hence, does not represent the actual probability of rock slides into the lakes. For a given area, more detailed investigations of the geology, triggering factors and frequency of previous rock slide events should be carried out before definite statements about the actual hazard can be made.
\end{abstract}

\section{Introduction}

Rock slides and rock falls are relatively frequent in Norway. Furseth (2006) has recorded almost 800 such events over the

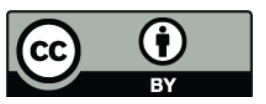

Correspondence to: B. Romstad

(bard.romstad@cicero.uio.no) last 500 years causing the loss of the approximately 500 lives. The real number of events is probably much higher due to a lack of reporting of such historic events when lives are not lost. The majority of lost lives can be attributed to a few catastrophic rock slides that have occurred with a frequency of about 2 to 4 per century. Rock slides have been especially devastating when plunging into lakes or fjords. During the 20th century we experienced three such events in Norway (Loen in 1905 and 1936, Tafjord in 1934) where the consequent tsunamis caused a total loss of 174 lives (Furseth, 2006). Clearly a detailed study of rock slide hazard in lakes and fjords in Norway is desirable, but in a country with more than 200000 lakes and $25000 \mathrm{~km}$ of coastline (numbers based on 1:50000 digital maps) such a study will require a huge amount of resources. Hence, there is a need to identify areas where to focus our studies.

This paper suggests a method for calculation of topographic rock slide and tsunami potential for a set of lakes. This is expressed as an index of the rock slide threat for each lake, based on its topographical setting alone. The index should not be interpreted as a measure of rock slide susceptibility, but is merely an indication of which lakes have a topographical setting that favours tsunami generating rock slides. The method also defines which areas around a given lake may serve as potential release areas and the mobility required for a slide to reach the lake if released at any point. This "mobility surface" effectively delineates the spatial extent of the problem and can therefore be used to guide the collection of additional data. Due to the extremely large areal extent of the analysis the method is designed to make use of a minimum of input data and efficient algorithms in the data processing. 


\section{Background}

\subsection{Hazard evaluation for sliding processes}

The goal of hazard evaluation for sliding processes is to quantify the probability of occurrence of a potentially damaging event within a given area and a given period of time. A growing demand for such analyses, together with increasing availability of environmental data (e.g. high resolution digital elevation models, DEMs), advances in technology (especially Geographical Information Systems, GIS) and tools for modelling and simulation, have spurred the development of this field during the last decades (Carrara and Pike, 2008). A review and categorization of some different groups of methods are found in Guzzetti et al. (1999), but typically methods range from empirical and heuristic to statistical and physically-based models (Carrara and Pike, 2008).

Modelling of different landslide hazards can be approached statistically by establishing a relationship between historical events and a set of relevant factors such as terrain morphology, geology, lithology, land cover etc (e.g. Carrara et al., 1991; Guzzetti and Reichenbach, 1994). Obviously this requires that relevant data exist over the whole study area. In addition landslide inventories that can be used to establish the statistical model must exist. In many cases, as is the case for Norway, inventories may be sparse and incomplete. Thus the validity of such a model may be questionable. In addition the statistical model will usually result only in the probability of a mapping unit being stable or not, with no explicit separation between release and run out area; thus it may be difficult to evaluate the hazard to a given spatial feature (e.g. a building, road or a lake) unless it lies within the potentially unstable mapping unit.

From a process point of view, regional modelling of landslide hazard can be divided into two main parts. First, potential release areas and their properties (potential slide volume) must be defined. The result of this analysis is then used as input when modelling run-out distance for each individual slide. Preferably some measure of probability should be attached to release areas, their volume and the slide run-out distances. While physically based models may be appealing, they are not always suitable for regional modelling. The main reason for this is that the models often require input data at a level of detail that is unavailable over large regions. In addition the use of such models may be impractical due to the processing time needed to run them over large areas, especially if probabilities need to be introduced via stochastic modelling or Monte Carlo simulations (see e.g. Perla et al., 1984; Harbitz et al., 2001a). There are, however, a number of models that have been used in regional studies for modelling slope instability (e.g. Montgomery and Dietrich, 1994; Crosta and Frattini, 2003) and/or defining run-out zones (e.g. Guzzetti et al., 2002a; Dade and Huppert, 1998; Iverson et al., 1998; Jaboyedoff and Labiouse, 2003; Lan et al., 2007). These types of models are based on a more or less simplified physical description of the process and make use of a digital elevation model (DEM). Models for defining unstable rock slopes are less developed than those for shallow landsliding. The data requirements for defining potential rock fall or rock slide release areas can be quite exhaustive, especially when the model is supposed to cover a large geographical area. In the case of rock slopes, release is dependent on conditions such as geological fractures and subsurface hydrology along with triggering factors such as climatic events or earthquakes. The significance of each of the factors may vary considerably between different locations and often one finds that the required data are not available on a suitable scale. The availability of intermediate to high resolution DEMs is the fortunate exception, and some DEM based methods for estimating rock slope instabilities have been suggested (Günther, 2003; Jaboyedoff et al., 2004). Still in many regional models for rock falls or slides, potential release areas are either defined manually or based on local slope angle alone.

Considering the above we must accept that a regional model of rock slide hazard that is generally applicable to all of Norway is unfeasible due to the data requirements. In many cases, however, our ultimate concern is the rock slide risk to a given set of geographical features. If we can define the features of concern beforehand we may limit the maximum spatial extent of the potential areas for release zones dramatically using simple assumptions about rock slide movement. In addition, some statistical relationships between rock slide volume and mobility, coupled with an estimate of the frequency magnitude distribution of events, may provide an estimate of the rock slide threat to different features relative to each other.

\subsection{Mobility and volume of a rock slide}

Figure 1 shows a simplified sketch of a rock slide including some basic attributes: the slide height $(H)$, the run-out length $(L)$ and the run-out angle $(\alpha)$. The mobility of a rock slide can be expressed as $H / L$. The smaller this ratio is, the smaller is the run-out angle $(\alpha)$ between headwall and toe, and the higher is the mobility of the slide.

For rock slides with a volume smaller than about $10^{5} \mathrm{~m}^{3}$ motion is governed by the dry friction. Hence, the runout angle is restricted by the friction angle of the material in question (usually around $30^{\circ}-40^{\circ}$ ) and is not dependent on the slide volume (e.g. Scheidegger, 1973; Hsü, 1975; McEwen, 1989; Legros, 2002). This is supported by empirical data; e.g. Keylock and Domaas (1999) reports maximum run-out for rock falls $\left(<10^{4} \mathrm{~m}^{3}\right)$ at angles no lower than $31^{\circ}$. For larger slides, however, the run-out angle becomes smaller as the volume increases. The physical explanation for long run-out rock slide mobility is not entirely understood, but a short summary of different hypotheses put forward to explain this can be found in Legros (2002). Empirically it has been shown that there is a fairly robust statistical relationship be- 
tween rock slide volume $(V)$ and rock slide mobility $(H / L)$, as suggested by Scheidegger (1973):

$\log _{10} \frac{H}{L}=a \log _{10} V+b$

where $V$ is in $\mathrm{m}^{3}$ and the constants $a$ and $b$ set to -0.15666 and 0.62419 , respectively.

Table 1 and Fig. 2 contain a number of large Norwegian rock slides published by NGU (2001). The figure illustrates that the Norwegian slides are in good agreement with Scheidegger's volume-mobility relation.

Equation (1) can be rearranged to solve for volume:

$V_{\min }=\left(\frac{H}{10^{b} L}\right)^{\frac{1}{a}}$

$V_{\text {min }}$ now represents the minimum volume required to arrive at the run-out angle $H / L$. As mentioned earlier, small rock slides are governed by dry friction so Eq. (2) is only valid for slides larger than about $10^{5} \mathrm{~m}^{3}$, that is when $H / L$ is smaller than the internal friction angle of the material involved (about 0.7).

Figure 3 shows how Eq. (2) can be used to estimate the minimum volume required to reach a lake for slides released at three different locations. At points where $H / L$ is low only a very large slide will have high enough mobility to reach the lake and as $H / L$ increases the minimum required volume decreases. In areas where $H / L$ exceeds the normal friction coefficient $(H / L>0.7) V_{\min }$ is undefined as any slide, regardless of volume, may reach the lake from here.

\subsection{Properties of the rock slide and a resulting tsunami}

The destructive power of a rock slide increases with its magnitude. This is also true for the resulting tsunami should a slide plunge into a lake. It may be fair to say, however, that under most conditions a tsunami that occurs in a lake will have a destructive impact. As an example, a moderate wave with an initial surface elevation of $20 \mathrm{~m}$ at a distance of $25 \mathrm{~m}$ seaward from the slide area will have to travel at least $10 \mathrm{~km}$ before the height is reduced to $1 \mathrm{~m}$. Moreover, this holds only if free radial wave spreading is possible. Consequently we must assume that in Norwegian lakes, which are typically long and narrow, the magnitude of a tsunami will not be considerably reduced before it reaches any part of the shoreline. In addition settlements are often situated at gently sloping areas close to the shores. Such terrain also favour wave amplification, which means that risk to life and property may be high even for low magnitude events. For reasons of simplicity we can thus define the hazard as being constant with event magnitude (above a given threshold), and only dependent on the frequency.

The two main rock slide parameters governing the initial height of a tsunami are the frontal area and the velocity of the rock slide at the time of impact with the water (Harbitz et al., 2006). It is known that rock slides with a volume of

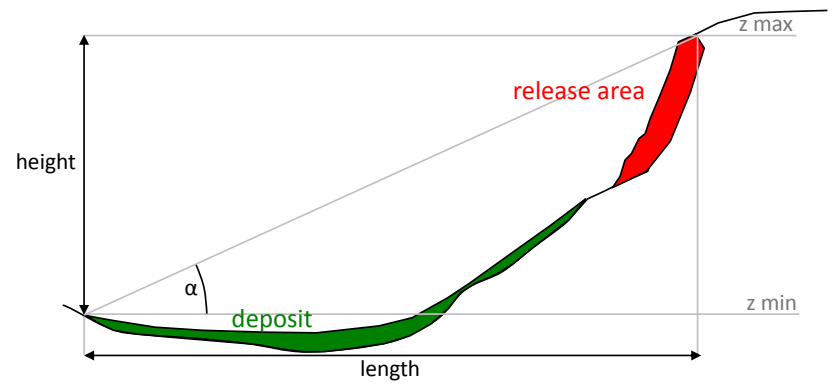

Fig. 1. Geometry of a rock slide with definition of slide height $(H)$, length $(L)$ and run-out angle $(\alpha)$.

about $20000 \mathrm{~m}^{3}$ have caused severe destructions on the opposite side of the fjord (Harbitz et al., 2001b). On the other hand, the authors are not aware of any widespread (i.e. covering a significant part of a fjord or a lake) or destructive tsunami generated by a rock slide with a volume less than $5000 \mathrm{~m}^{3}$. This is confirmed by numerical simulations (e.g. NGI, 2006). Moreover, laboratory experiments and scaling relations of tsunami generation by various rock slide volumes, configurations, and impact velocities are discussed by e.g. Noda (1970), Wiegel et al. (1970), Slingerland and Voight (1979), Monaghan et al. (2003), Walder et al. (2003), Fritz et al. (2004), Zweifel et al. (2006), and Sælevik et al. (2009). By applying the empirical regression equation for maximum surface elevation deduced from three-dimensional laboratory experiments by Slingerland and Voight (1979), it is found that a rock slide with a volume of $5000 \mathrm{~m}^{3}$ and an impact velocity of $30 \mathrm{~m} / \mathrm{s}$ will generate a tsunami with surface elevation less than $1 \mathrm{~m}$ at a water depth of $100 \mathrm{~m}$ and a distance of $25 \mathrm{~m}$ outside the slide area. Due to the significance of bathymetry, radial spreading, reflection, etc., wave height predictive equations from rectangular 2-D wave channel or 3-D wave tank models should be applied to site specific situations with caution. Hence, if we use slide volume as a proxy for frontal area we can say that only slides with volumes larger than about $5000 \mathrm{~m}^{3}$ will generate a destructive wave. Due to the large variability in observed maximum rock slide velocities, and the corresponding uncertainties in rock slide impact velocities, it can further be assumed that every slide that reaches the shore line with a volume larger than the required minimum will also have an impact velocity large enough to generate a tsunami. This is a conservative assumption, not excluding any potential tsunami generating rock slide due to low velocity.

\subsection{Magnitude frequency distribution of landslides}

The frequency of small rock slide events is much higher than the frequency of large events. Several studies have shown that the magnitude frequency distribution of events such as rock slides follow a power law distribution 


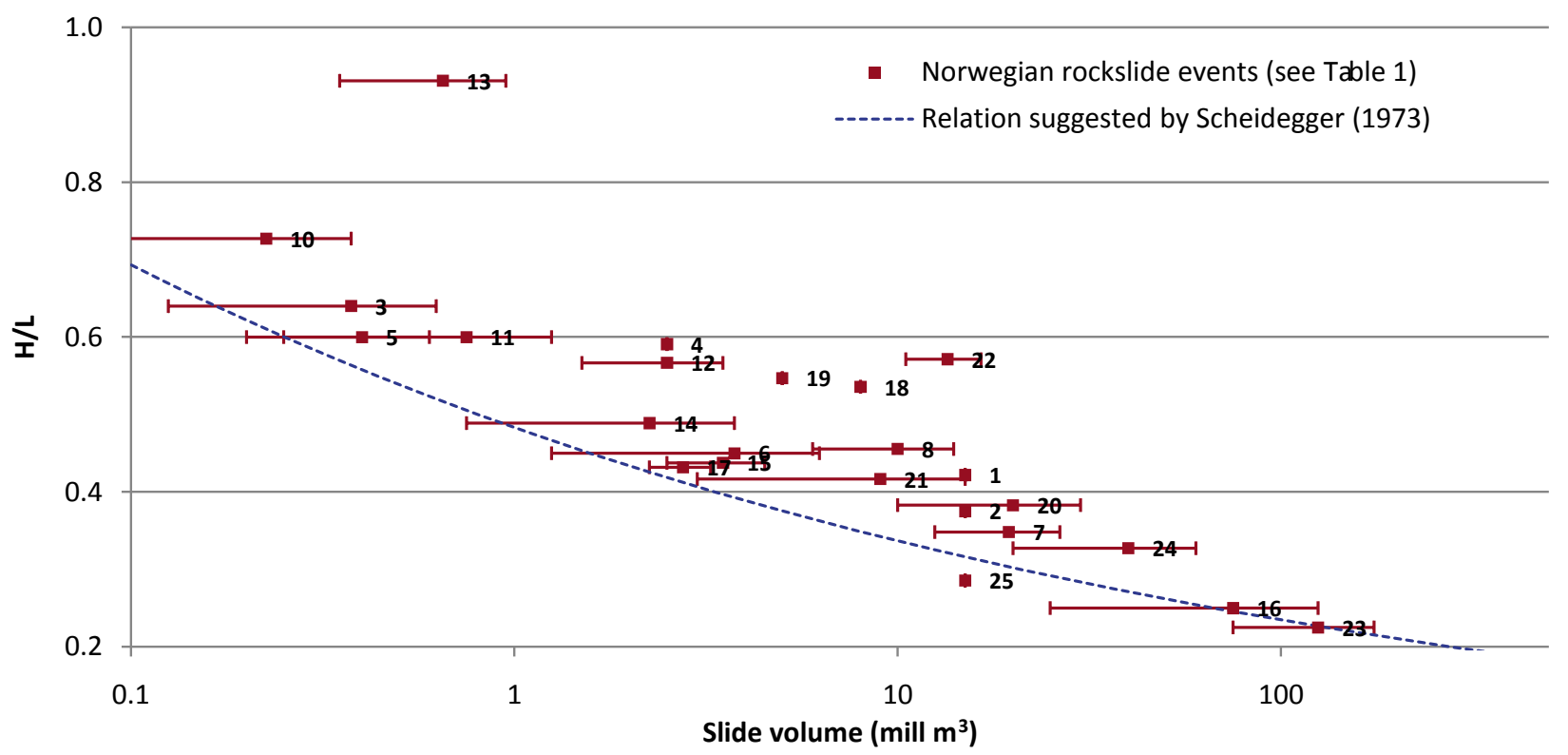

Fig. 2. Slide mobility as a function of volume for the Norwegian rock slide events in Table 1 . The error bars indicate minimum and maximum volume estimates.

Table 1. Properties of a number of Norwegian rock slides (NGU, 2001).

\begin{tabular}{|c|c|c|c|c|c|}
\hline No & Name & $\begin{array}{c}\text { Vol } \\
\text { (mill m3) }\end{array}$ & Height & Length & $\mathrm{H} / \mathrm{L}$ \\
\hline 1 & Verkilsdalen, Rondane & 15 & 675 & 1600 & 0.42 \\
\hline 2 & Tjelle, Langfjorden & 15 & 750 & 2000 & 0.38 \\
\hline 3 & Melkevoll, Olden & $0.25-0.5$ & 480 & 750 & 0.64 \\
\hline 4 & Rørsetura, Oterøya & 2.5 & 650 & 1100 & 0.59 \\
\hline 5 & Gravem, Sunndal & $0.3-0.5$ & 900 & 1500 & 0.60 \\
\hline 6 & Sørdalen, Vanylven & $2.5-5$ & 675 & 1500 & 0.45 \\
\hline 7 & Urdabøuri, Vinje & $16-23$ & 470 & 1350 & 0.35 \\
\hline 8 & Erdalen, Stryn & $8-12$ & 460 & 1010 & 0.46 \\
\hline 9 & Hjelle, Stryn & 0.5 & 730 & 575 & 1.27 \\
\hline 10 & Bjørkum, Lærdal & $0.15-0.3$ & 400 & 550 & 0.73 \\
\hline 11 & Furuneset, Tafjorden & $0.5-1$ & 900 & 1500 & 0.60 \\
\hline \multirow[t]{2}{*}{12} & Langhammaren, & & & & \\
\hline & Tafjorden & $2-3$ & 850 & 1500 & 0.57 \\
\hline \multirow[t]{2}{*}{13} & Grande, & & & & \\
\hline & Geirangerfjorden & $0.5-0.8$ & 1350 & 1450 & 0.93 \\
\hline \multirow[t]{2}{*}{14} & Hysket, & & & & \\
\hline & Geirangerfjorden & $1.5-3$ & 550 & 1125 & 0.49 \\
\hline \multirow[t]{2}{*}{15} & Stølaholmen, & & & & \\
\hline & Fjørland & $3-4$ & 420 & 960 & 0.44 \\
\hline \multirow[t]{2}{*}{16} & Berrføttene, & & & & \\
\hline & Fjærlandsfjorden & $50-100$ & 1000 & 4000 & 0.25 \\
\hline \multirow[t]{2}{*}{17} & Frykkjelen, & & & & \\
\hline & Fjærlandsfjorden & $2.5-3$ & 950 & 2200 & 0.43 \\
\hline 18 & Kubergan N, Troms $\varnothing$ & 8 & 375 & 700 & 0.54 \\
\hline 19 & Kubergan S, Troms $\emptyset$ & 5 & 350 & 640 & 0.55 \\
\hline 20 & Nakkevatnet, Lyngen & $15-25$ & 900 & 2350 & 0.38 \\
\hline 21 & Grøtlandsura, Salangen & $6-12$ & 500 & 1200 & 0.42 \\
\hline 22 & Skjærsura, Valldal & $12-15$ & 1000 & 1750 & 0.57 \\
\hline 23 & Hellaren, Grovfjorden & $100-150$ & 900 & 4000 & 0.23 \\
\hline 24 & Gumpedalen, Sørreisa & $30-50$ & 720 & 2200 & 0.33 \\
\hline 25 & Store Urdi, Jotunheimen & 15 & 400 & 1400 & 0.29 \\
\hline
\end{tabular}

(e.g. Guzzetti et al., 2002b; Hergarten, 2003, 2004; Malamud et al., 2004). Such a distribution can be written as:

$N(V) \sim V^{-\beta}$

where $N(V)$ is the number of slides per time interval with a volume $V$ or larger and $\beta$ is a constant parameter. This can also be looked upon as a normalized a priori probability for a slide with volume $V$ or larger to occur in an area within a given time period. The higher the exponent, $\beta$, the lower is the probability of large events relative to smaller events. Based on a number of inventories of rock falls and slides from subvertical cliffs, Dussauge et al. (2003) propose that volume distributions follow a power law distribution with an average exponent of $0.5 \pm 0.2$ on a $10^{-3} \mathrm{~m}^{3}$ to $10^{10} \mathrm{~m}^{3}$ volume range. For mixed landslides Dussauge et al. (2003) reported that exponent values averaged $1.2 \pm 0.3$, while Hergarten (2003) reported exponent values for landslides in the range 0.7 to 1.0 (1.0 to 1.6 for landslide area, rather than volume, distributions).

\section{Method}

\subsection{Input data and calculations}

The input data used in this study was a $25 \mathrm{~m}$ raster based digital elevation model and a 1:50 000 vector map with lakes. The lake map contained more than 200000 individual water bodies, but for this analysis we excluded all lakes with an area less than $0.1 \mathrm{~km}^{2}$. This was both because we wanted to reduce the number of lakes to analyze, but also because we judged the threat from a potential tsunami in these small lakes to be very small. 


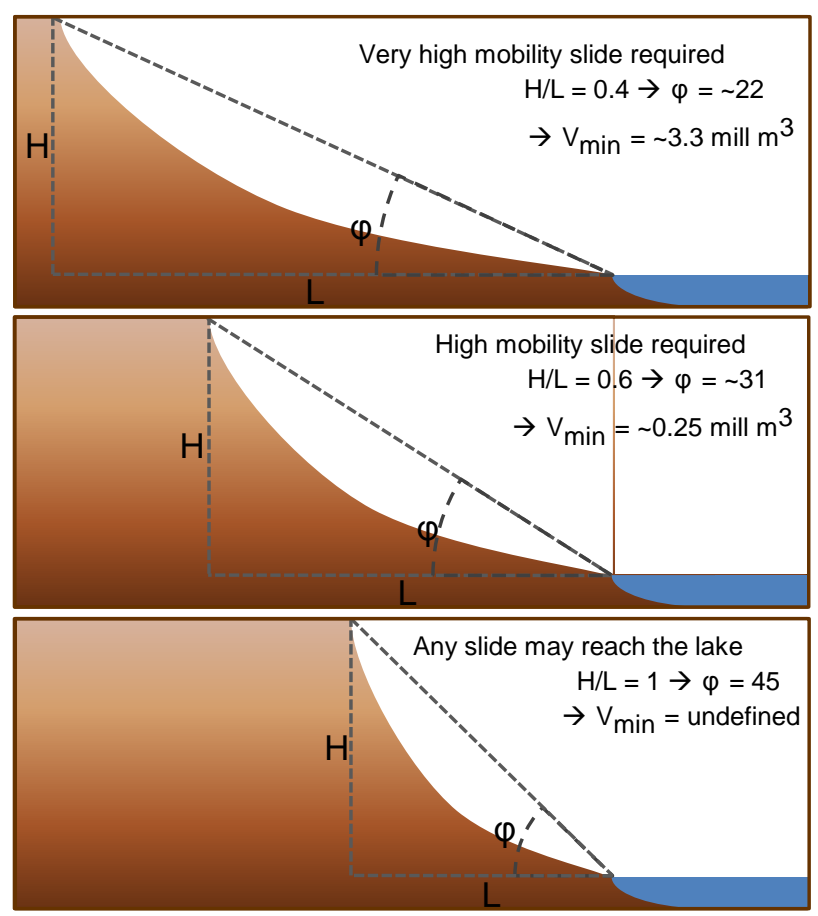

Fig. 3. Example of minimum required volumes to reach a lake for three $\mathrm{H} / \mathrm{L}$ values.

The basic idea behind the method is to identify all potential release cells around each lake based on a slope criterion alone. Furthermore we give each potential release cell a weight based on its position relative to the lake. The assumption is that the probability of a tsunami generating rock slide release is high in steep slopes directly above the lake compared to more distal slopes. A simple sketch of the methodology for calculation of these weights is shown in Fig. 4. For a given point, $p$, the vertical distance $(H)$ and the horizontal distance along a travel path $(L)$ to a candidate lake can be calculated. The ratio between these two distances $(H / L)$ yields the mobility required for a slide released at that point to reach the lake. Using Eq. (2) we can estimate the volume required to achieve this mobility $\left(V_{\min }\right)$. This means that at point $p$, any slide larger than $V_{\min }$ may reach the lake, and thus generate a tsunami. We also know that large slides are less common than smaller slides and by applying Eq. (3) to the result of Eq. (2) we can estimate the probability that an event of size $V_{\min }$ or larger will occur relative to another event with size $V_{\text {min }}$ ' or larger. This probability is only a function of the topographical setting of the investigated point and the lake. It can be looked upon as a topographic tsunami-generating potential, TTGP, for a rock slide initiated at this point.

Since Eq. (2) is invalid when $H / L$ yields an angle steeper than the internal friction angle it will overestimate the minimum required volume, $V_{\min }$, in areas where $H / L$ is steep enough for any slide volume to reach the lake. Consequently Eq. (3) will underestimate the tsunami generating potential in these areas. In addition $V_{\min }$ should be constrained down-

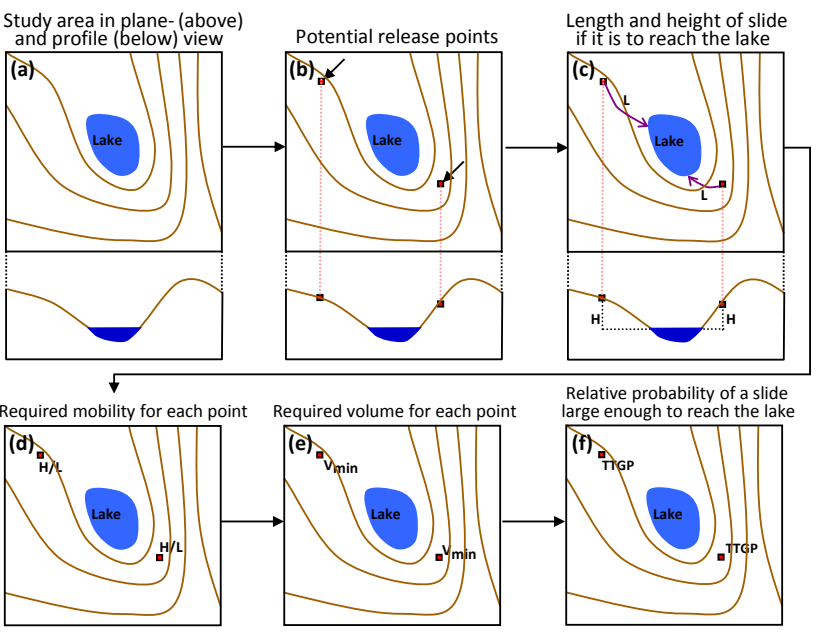

Fig. 4. Flow chart showing how the relative probability of a tsunami generating slide to be released at any point is estimated.

wards by a minimum damaging volume, $V_{d}$, which in our case is the minimum volume required for a rock slide to create a destructive wave. We therefore define TTGP as follows:

$\mathrm{TTGP}=\left\{\begin{array}{l}\max \left(V_{\min }, V_{d}\right)^{-\beta} V_{d}^{\beta}, \frac{H}{L}<f \\ V_{d}^{-\beta} V_{d}^{\beta}=1, \frac{H}{L}>=f\end{array}\right.$

When $H / L$ is smaller than the internal friction angle, $f$, TTGP is obtained by applying Eq. (3) to the maximum of $V_{\min }$ and $\mathrm{V}_{d}$ and then normalizing it so that TTGP has a maximum value of 1.0 where $V_{\min }$ equals $V_{d}$. When $H / L$ is larger than or equal to $f, V_{\min }$ should be substituted with $V_{d}$ and TTGP will always be 1.0. $V_{\min }$ is the output of Eq. (2) and we used constants $a$ and $b$ as estimated by Scheidegger (1973) $(a=-0.15666, b=0.62419)$. For $\beta$ we used 0.7 which is in the upper range of reported values for rock falls and in the lower range of reported values for mixed landslide types (Dussauge et al., 2003; Hergarten, 2003). $V_{d}$ was set to a conservative estimate of $5000 \mathrm{~m}^{3}$ and the friction angle $f$ was set to 0.7 (about $35^{\circ}$ ).

Figure 5 shows $V_{\min }$ and TTGP as a function of $H / L$. For small $H / L$ values (areas far away from the lake) the rock slide volume required in order to reach the lake $\left(V_{\min }\right)$ is very large. Such large events are relatively rare and thus we have a low score on the probability measure (TTGP). As soon as $H / L$ exceeds the internal friction angle there is no longer a topographic constraint on the required volume $\left(V_{\min }\right)$ and all rock slides larger than the minimum damaging volume $\left(V_{d}\right)$ must be considered. This implicates a drastic positive shift in the probability measure that is explained by a change in the physics of the rock slide motion for small versus large rock slides.

For a given lake we can calculate a total "topographic (tsunami-generating) rock slide potential":

$\mathrm{TRSP}_{\mathrm{Lake}}=\sum_{i=1}^{n} \mathrm{TTGP}_{i}$ 


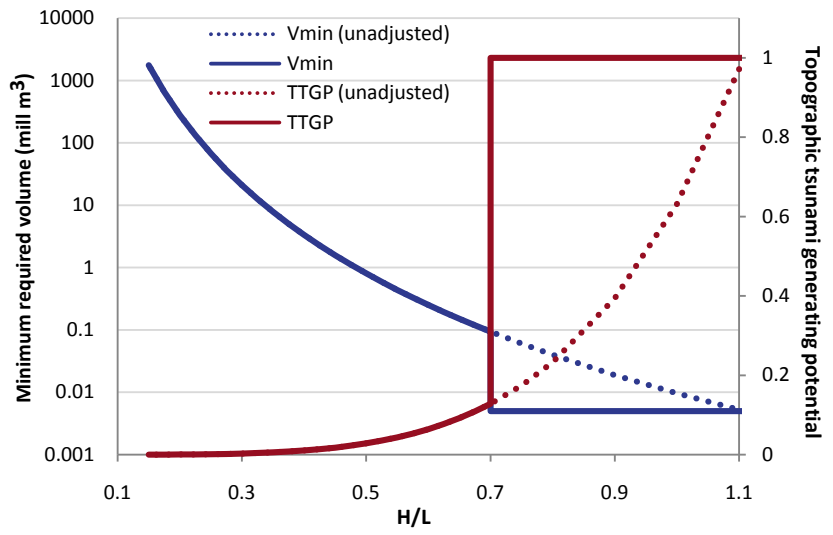

Fig. 5. Minimum required volume $\left(V_{\min }\right)$ and topographic tsunami generating potential (TTGP) for H/L values between 0.1 and 1.1. Dashed lines are unadjusted values directly from Eqs. (2) and (3), while the solid lines shows the effect of substituting $V_{\min }$ with $5000 \mathrm{~m}^{3}$ at $\mathrm{H} / \mathrm{L}$ values above 0.7 .

by summarizing all the TTGP values of the potential release cells in the vicinity of the lake. This yields a value that is comparable between different lakes. Obviously the TRSP value increases with the number of potential release cells, but each cell's contribution to the total TRSP value decreases with $H / L$.

\subsection{GIS processing}

For the GIS processing we used the ArcGIS 9.2 software. Considering the large geographical area we are covering in this study we found no feasible way to identify areas where rockslides may be released other than a threshold for local slope angle. Thus a slope layer was calculated from the DEM and cells with an angle above $30^{\circ}$ were marked as potential release areas. This slope threshold is smaller than the angle of internal friction for most rock types and can thus be regarded as conservative.

For any potential release area, our only concern is whether a slide released there will reach a lake or not. If we assume that rockslides follow the D8 flow direction (O'Callaghan and Mark, 1984) this effectively means that each lake's potential release area is narrowed down to its own catchment area. Thus we can establish a relationship between each potential release cell and its candidate lake. This is important because with a cell based DEM and a map of the lake polygons we are now able to use a set of GIS operations to calculate the TTGP value not for just one single point, but for all cells in the DEM at the same time.

Given a more or less hydrologically consistent DEM, a new layer (CATCHMENTS) with labelled regions representing each lake's catchment area can be efficiently computed in most GIS software. The elevation difference between each potential release cell and the minimum elevation within the catchment yields the elevation drop between the release cell and its candidate lake. This was saved to a second layer (HEIGHT). The Euclidian distance between each release cell and its candidate lake could be used as a most conservative value for required run-out length, but this would most often lead to a large underestimation of the distance. Instead we calculated the run-out distance along the D8 flow directions (flow length) and saved this to a third layer (LENGTH).

Equations (2) and (4) were next applied to the HEIGHT and LENGTH layers to produce layers with minimum required volume $\left(V_{\min }\right)$ and topographic tsunami-generating potential (TTGP) for all the potential release cells. In the end all the TTGP values within each lake's catchment area could be summarized to a topographic rock slide potential (TRSP) for each lake and saved to a table together with the lake id number, thus making further analysis of the results practical.

While for a regional analysis it was important to express the rock slide potential as one single number for each lake, the intermediate steps in the methodology provided information in the form of geographical layers that could be used for a more comprehensive analysis of a limited area. For example the map of minimum required volumes can be used directly to pinpoint where potential release areas may be, and the rock slide volume required for a slide released here to reach the lake. Along the coastline of a given lake it may also be of interest to know where the most probable points of rock slide impact are. We calculated this by routing the TTGP in each cell downstream towards the shore of the lakes in order to show the distribution of accumulated TTGP values along the shore line. A multiple flow algorithm (Freeman, 1991) was used to iteratively distribute the TTGP value in each cell down to all lower lying neighbours until the shore line was reached. The fraction of TTGP passed from a cell to neighbour $i$ is given by

$$
f_{i}=\frac{\max \left(0, S_{i}^{p}\right)}{\sum_{i=1}^{8} \max \left(0, S_{i}^{p}\right)}
$$

In the end, the probability in each cell along the shore line was the sum of all the upslope probabilities. The method produces results equivalent to the calculation of a weighted specific catchment area in hydrology (Quinn et al., 1995) and it can be looked upon as a map of the most probable slide paths and the most probable points of impact.

\section{Results and discussion}

The final result of the analysis is a list of all lakes with the sum of probabilities within their catchment area. This sum can be looked upon as a topographic rock slide potential for the lake as it summarizes the probability of slides initiated 

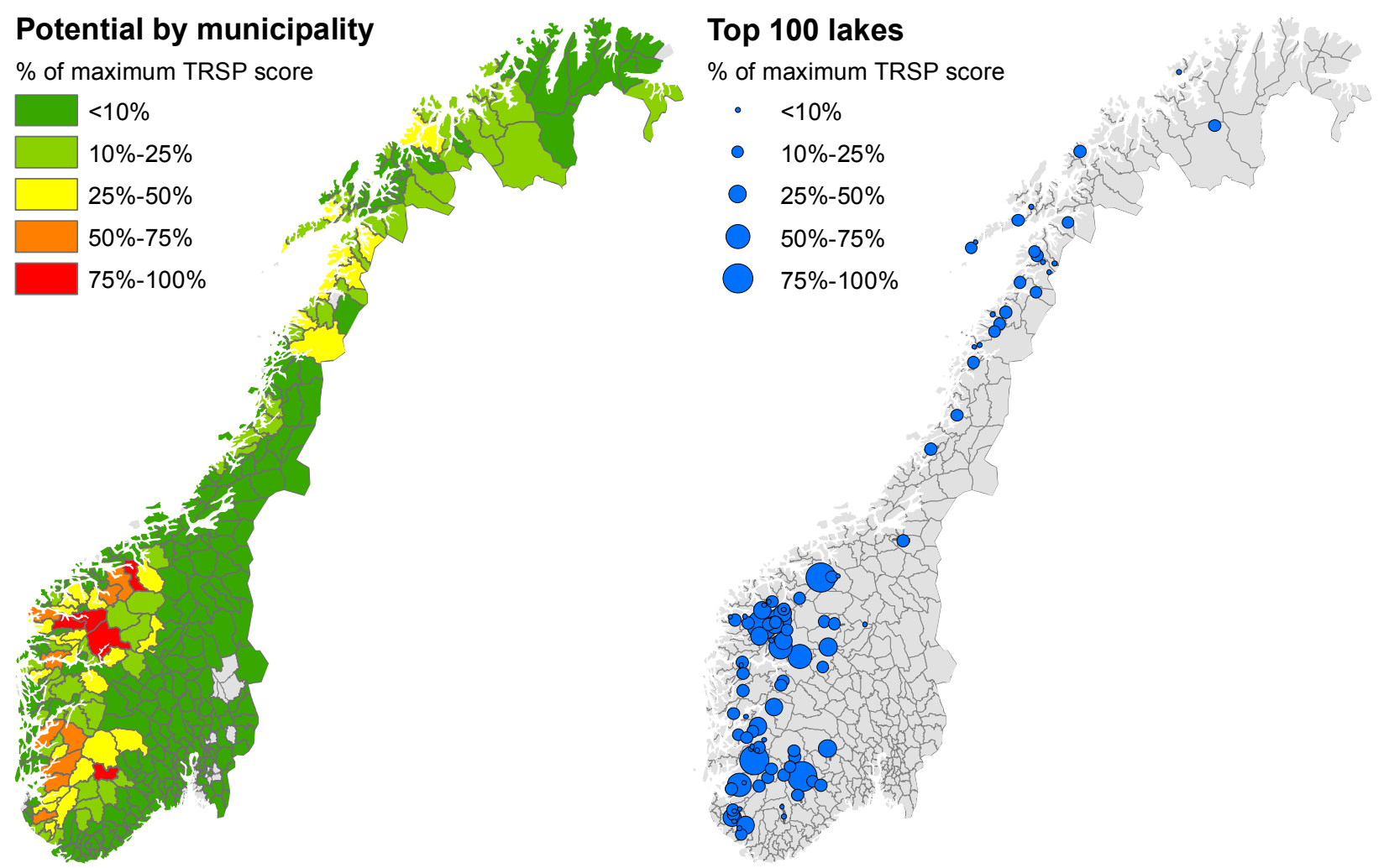

Fig. 6. Geographical distribution of rock slide potential within municipalities (left) and the 100 lakes with highest rock slide potential (right). The potential is expressed in percent of the maximum value for both maps.

within the catchment actually reaching the lake. The potential can also be summarised by larger hydrological units or even by administrative units to better illustrate the geographical distribution of the problem.

Out of the 18976 lakes investigated, 12215 were reported as having rock slide potential. But most of them received a very low score. About $1 / 3$ of the total potential came from the contribution of the 11500 lakes with the lowest score, then the next 600 lakes contributed to the second $1 / 3$ while the last $1 / 3$ of the total rock slide potential came from the top 100 lakes. Expressed in another way, the vast majority of the lakes $(90 \%)$ received a score lower than $1 \%$ of the maximum score, and about $63 \%$ received less than $0.1 \%$ of the maximum. This skewed distribution of scores indicates that the topographic rock slide potential is negligible for a large portion of the lakes.

Since the ranking of the lakes is based on the topographic potential alone, it is problematic to categorically disregard the potential for any of the lakes, however low the score value. We have assumed that even quite small slides $\left(>5000 \mathrm{~m}^{3}\right)$ may create a destructive tsunami if they reach a lake. Thus, areas where the minimum required volume is low, in that both small and large slides may reach the lake, gain a relatively high score compared to areas where only large slides will have sufficient mobility to reach the lake. One could argue that it is these large slides we really should worry about; in that case the same methodology could be used, but with a larger volume defined as the "minimum destructive volume". This would lead to a less distinctive skewing of the distribution of scores, as the analysis would include a smaller range of possible slide volumes, but the relative rank of each lake would not change significantly. The same effect could be achieved by setting the exponent value $\beta$ in Eq. (4) to a lower value. Ideally locally adapted values should be used for the exponent so that the influence of large slides will be reflected in the actual frequency-magnitude distribution in each area. While the use of a spatially distributed estimate of $\beta$ is quite possible, it is questionable whether the effort of estimating it would be warranted for this type of preliminary analysis.

Figure 6(left panel) shows the relative potential for rockslides into lakes by municipality. The pattern shown here coincides well with known problem areas in parts of Western Norway (mainly Rogaland, Sogn og Fjordane and Møre og Romsdal counties), as well as a few areas in Northern Norway. Figure 6(right panel) illustrates clearly that the geographical pattern is well explained by a small fraction of lakes (top 100) that received a very high score in the analysis. Among the top 100 lakes we find several lakes with known rock slide hazard. As an example the Lovatnet lake, which experienced catastrophic tsunamis in both 1905 and 1936, is among the top 10 lakes on the list (see Appendix A and Fig. 7). 


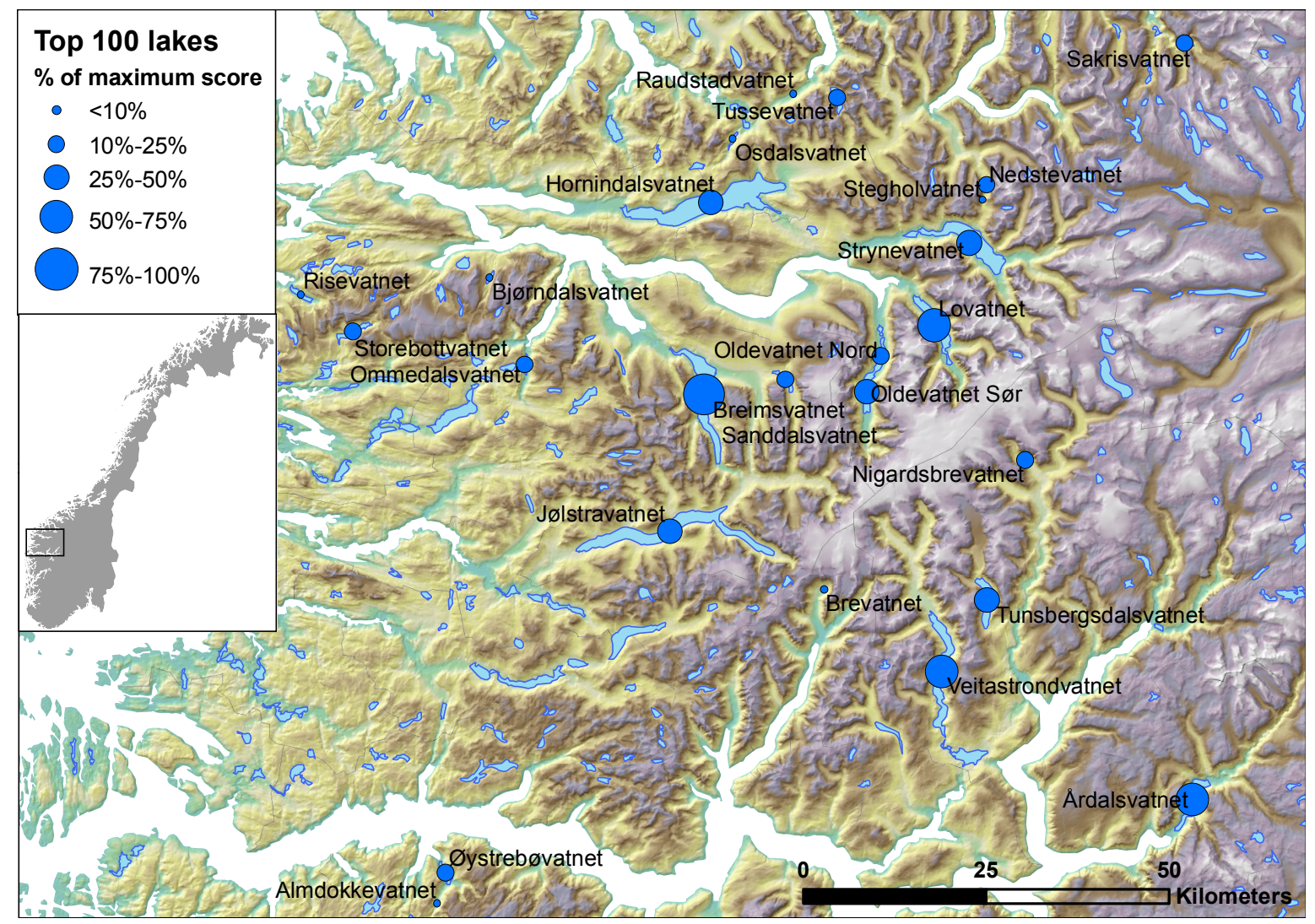

Fig. 7. Lakes with high potential: Detail from the area between Sognefjorden and Nordfjord.

While the methodology does not explicitly consider that the frequency of events varies between different regions in Norway, this is partly taken care of as rock slide activity is highly correlated with steep topography. Thus there will be more potential release cells and consequently higher TRSP values for lakes in these areas. However, the geological and triggering components of the large scale geographical variation of sliding activity are still not accounted for in this model.

As we have seen, the list of topographic rock slide potential (TRSP) for individual lakes reveals the spatial distribution of the problem. It can also be used as a tool to point out lakes which may be particularly exposed (topographically) to rockslides and thus should be investigated further. It is also important to note that out of the top 100 lakes, 46 are hydropower reservoirs. Public regulations in Norway require that dam owners assess the consequences of a potential dam break and subsequently place the dam in a consequence class according to Table 2. As can be seen from the table most of the 46 reservoirs have dams that are either class 2 or 3 (medium and large consequences).

The results can also provide useful qualitative information about the topographic conditions in a specific area with regard to rock slide threat. In Fig. 8 the minimum required mobility and volume surfaces around Sakrisvatn in Norddal
(Møre og Romsdal county) are shown. These maps may be used to pinpoint where field studies should be carried out, and during a field campaign they may be used to eliminate areas that are susceptible to failure, but where the potential slide volume would be too small to reach the lake if a failure took place. In the figure we have marked two areas where field studies (NGI, 2004) have indicated potential release volumes of $48000 \mathrm{~m}^{3}$ (A) and $112000 \mathrm{~m}^{3}$ (B). From the map we see that these rockslides would without a doubt reach the lake as the release areas are located in the area where even small slides may reach the lake.

In this study we limited our analysis of rock slide threat to lakes, but the same method could also be applied to fjords. Figure 9(left panel) shows a map of the relative probability that a tsunami generating slide will be released at any point for Tafjord. This is a part of Storfjorden where a rock slide induced tsunami killed 40 people in 1934. In the right panel these probabilities are routed downstream towards the shore. The analysis thus indicates the most probable points of impacts along the shore line. This information may be used to locate scenarios for more detailed modelling of potential tsunamis.

The parameters in the TTGP calculation in Eq. (4) are controlling the influence due to the topographic position of each potential release cell on the final TRSP score. To in- 


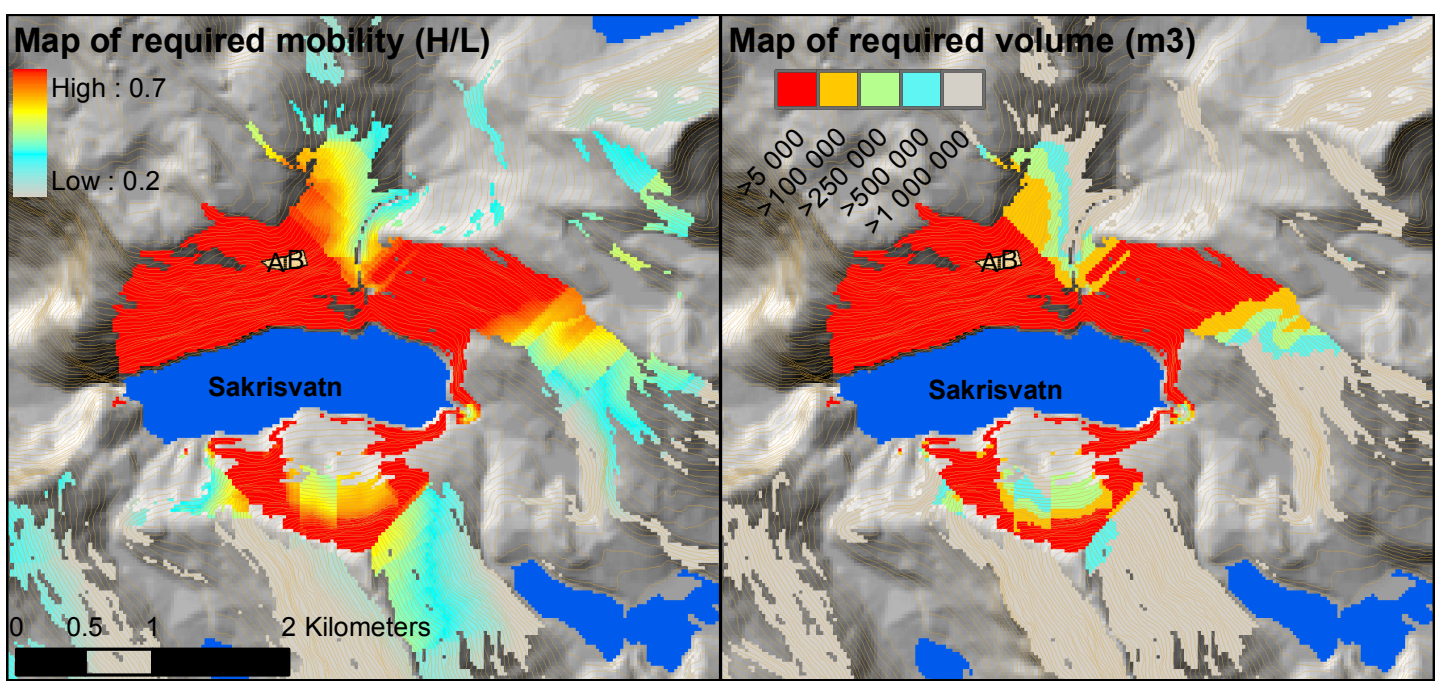

Fig. 8. Surface of minimum required mobility (left) and minimum required volume (right) for Sakrisvatn (Norddal, Møre andRomsdal). The two potential release areas mapped from field studies (A and B) are also shown.

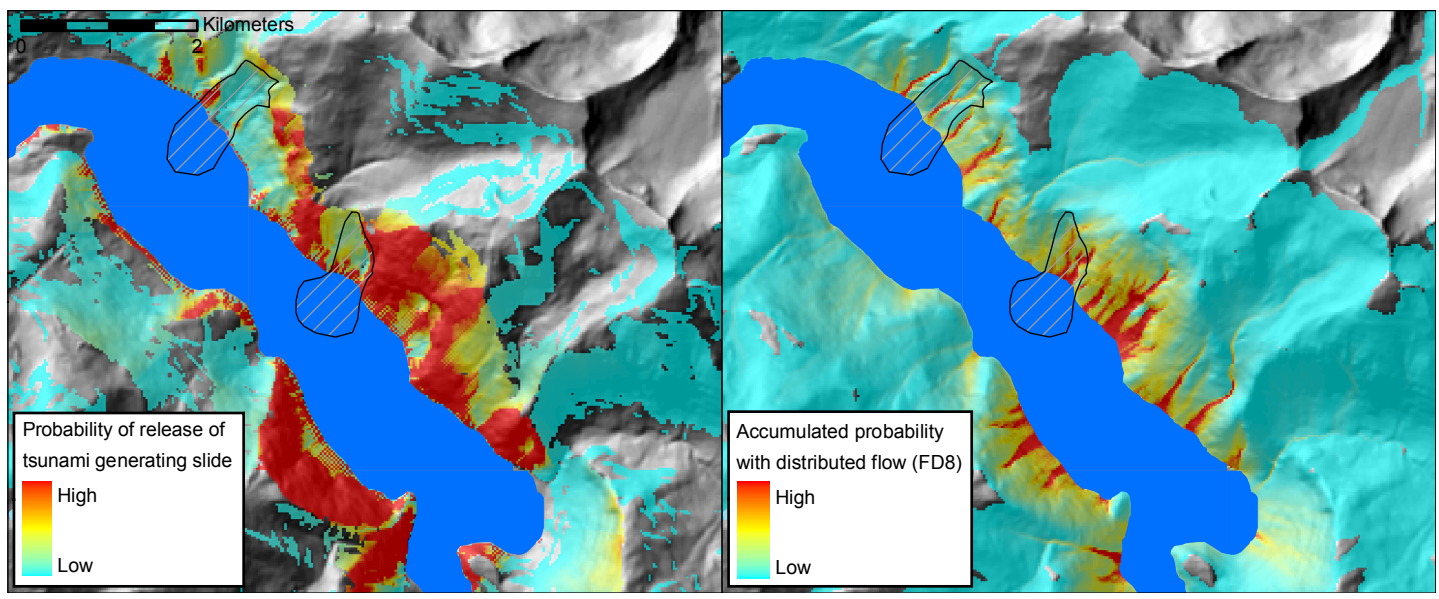

Fig. 9. Tafjord area, Western Norway. Left panel: Topographic potential for a rock slide initiated in any cell to reach the fjord (TTGP). Right panel: A map of most probable points of impact calculated by routing the probabilities downstream. Deposits of two historical rockslides are indicated.

vestigate the sensitivity of the result to these parameters we studied how the TRSP scores for the top 20 lakes changed as these parameters varied within a range of realistic values. This was then compared to a simple count of all the steep cells in the lake's catchment area, which is the naïve approach where the TTGP value is assumed to be 1.0 for all potential release cells, regardless of topographic position relative to the lake. The difference between the TRSP value and the cell count thus indicates how much the topographic position of the release cells influences the result with the given parameter settings.

The result of the sensitivity test is presented in Table 3 . Obviously the absolute TRSP score for each lake responds greatly to the parameter choices, but the relative score between the lakes remains quite consistent. We observe that
Table 2. Number of lakes (among the top 100) within different dam break consequence classes.

\begin{tabular}{lll}
\hline $\begin{array}{l}\text { Consequence } \\
\text { class }\end{array}$ & Explanation & $\begin{array}{l}\# \\
\text { reservoirs }\end{array}$ \\
\hline 0 & $\begin{array}{l}\text { No consequences } \\
\text { or unknown }\end{array}$ & 7 \\
& $\begin{array}{l}\text { Small consequences, } \\
\text { no residences affected } \\
1\end{array}$ & 9 \\
2 & $\begin{array}{l}\text { Medium consequences, } \\
1-20 \text { residences affected }\end{array}$ & 15 \\
3 & $\begin{array}{l}\text { Large consequences, } \\
>20 \text { residences affected }\end{array}$ & 15 \\
& & 46 \\
\hline
\end{tabular}


Table 3. TRSP scores using different parameter settings (indicated in the header row) for the top 20 lakes. See Appendix A for name and location of the lakes.

\begin{tabular}{|c|c|c|c|c|c|c|c|c|c|c|c|c|c|c|c|c|}
\hline Lake Id & $\begin{array}{l}\mathrm{f}=0.7 \\
\beta=0.7 \\
V_{d}=500\end{array}$ & & $\begin{array}{l}\mathrm{f}=0.6 \\
\beta=0.7 \\
V_{d}=5000\end{array}$ & & $\begin{array}{l}f=0.8 \\
\beta=0.7 \\
V_{d}=500\end{array}$ & & $\begin{array}{l}\mathrm{f}=0.7 \\
\beta=0.3 \\
V_{d}=500\end{array}$ & & $\begin{array}{l}\mathrm{f}=0.7 \\
\beta=1.0 \\
V_{d}=5000\end{array}$ & & $\begin{array}{l}\mathrm{f}=0.7 \\
\beta=0.7 \\
V_{d}=50\end{array}$ & 000 & $\begin{array}{l}f=0.6 \\
\beta=0.3 \\
V_{d}=50\end{array}$ & 000 & $\begin{array}{l}\text { count c } \\
\text { steep c } \\
\left(>30^{\circ}\right)\end{array}$ & of \\
\hline 1994 & & 25229 & & 38318 & & 18209 & & 39685 & & 23273 & & 36393 & & 60969 & & 121568 \\
\hline 22 & & 22326 & & 32741 & & 14748 & & 28055 & & 21349 & & 28219 & & 38447 & & 66648 \\
\hline 1800 & & 20600 & & 25252 & & 16641 & & 25410 & & 20029 & & 23921 & & 32453 & & 106897 \\
\hline 1864 & & 18927 & & 23672 & & 14217 & & 24962 & & 18242 & & 22840 & & 33395 & & 97249 \\
\hline 1806 & & 14603 & & 24343 & & 10082 & & 25095 & & 13345 & & 21824 & & 40388 & & 115941 \\
\hline 1571 & & 14220 & & 20445 & & 10733 & L & 19273 & & 13573 & & 18041 & 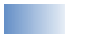 & 27169 & & 71000 \\
\hline 1604 & & 13680 & & 23824 & & 8977 & 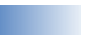 & 22839 & - & 12472 & & 20654 & 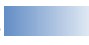 & 36907 & & 90894 \\
\hline 1683 & & 13465 & 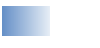 & 15117 & & 11693 & 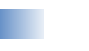 & 14704 & & 13296 & 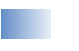 & 14466 & D & 16695 & & 24399 \\
\hline 2 & & 12609 & & 19145 & & 8579 & & 18381 & 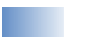 & 11787 & & 17368 & 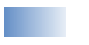 & 27375 & & 71181 \\
\hline 1524 & 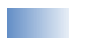 & 12475 & 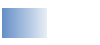 & 14439 & & 10670 & 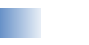 & 14057 & - & 12252 & 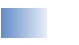 & 13789 & E & 16575 & 1 & 32548 \\
\hline 1734 & 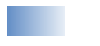 & 11947 & & 18326 & & 8186 & & 20668 & 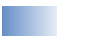 & 10945 & & 17578 & & 32794 & & 105312 \\
\hline 1807 & 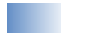 & 11432 & 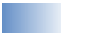 & 17319 & 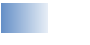 & 7774 & 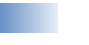 & 17831 & 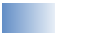 & 10590 & L & 16232 & 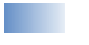 & 27251 & & 64928 \\
\hline 1889 & 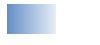 & 10857 & & 13688 & 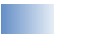 & 8357 & 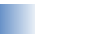 & 12800 & 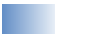 & 10558 & 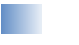 & 12624 & 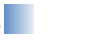 & 16042 & & 21500 \\
\hline 1802 & 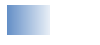 & 9989 & 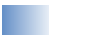 & 14858 & & 7017 & 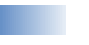 & 19564 & 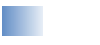 & 9122 & 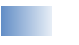 & 14739 & 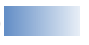 & 31811 & & 132743 \\
\hline 27288 & 1 & 8784 & & 14042 & & 6029 & 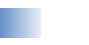 & 14133 & & 8138 & 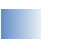 & 12493 & L & 22008 & & 61773 \\
\hline 147 & 1 & 7975 & & 11741 & & 5376 & & 12511 & & 7440 & 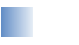 & 11025 & 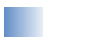 & 18947 & 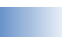 & 60511 \\
\hline 1400 & E & 7522 & & 9081 & & 6300 & & 9104 & & 7333 & & 8617 & & 11441 & & 36136 \\
\hline 825 & I & 7424 & & 10095 & & 4913 & & 10031 & & 7086 & & 9389 & I. & 13940 & & 35682 \\
\hline 1905 & I & 6586 & & 8192 & & 5508 & & 8445 & & 6393 & & 7699 & I & 11070 & 1 & 37716 \\
\hline 1274 & I & 6307 & & 8038 & & 4766 & & 8123 & & 6071 & & 7658 & & 10816 & & 24679 \\
\hline
\end{tabular}

reducing the value for $f$ (angle of friction) or $\beta$ (power law exponent), or increasing the value for $V_{d}$ (minimum damaging rock slide volume) brings TRSP values closer to the simple count of steep cells. This is expected as all of these adjustments will lessen the importance of topographic position (the importance of steep cells directly above the lake compared to steep cells further away from the lake). By setting all three parameters to their extreme at the same time an absolute minimum of topographic influence is assumed, but even at this setting it is evident that the topographic position strongly influences the result.

\section{Conclusions}

In this paper we have described a new approach for regional assessment of Norwegian lakes exposed to tsunami generating rockslides. The method successfully distinguished between lakes with high and low topographic rock slide potential. The results depict the geographical distribution of this hazard and they are useful as an entry point for further investigation. The intermediate results of the method may also serve as a tool to aid more detailed studies in a given area as they effectively define the spatial extent of the problem, describes properties of potential release areas (e.g. minimum required volume in order to reach the lake) and indicates probable points of impact along the shore line. Thus these maps can be used for planning field campaigns such as mapping of foliations relative to the topography near poten- tial release areas or mapping of movements within the potential release areas, using ground based or remote sensing techniques.

It is emphasised that the rock slide potential reported for each lake is based on the topographical setting alone and hence, does not represent the actual probability of rockslides into the lakes. For a given area, more detailed investigations of the geology, triggering factors and frequency of previous rockslide events should be carried out before definite statements about the actual hazard can be made.

The analysis does not include any considerations of vulnerability, risk or possible consequences of a tsunami. Obviously the socio-economical effect of a tsunami will primarily depend on the type of objects (infrastructure, buildings, people etc.) in the run-up zone and potentially also downstream. These factors should be included in a more detailed analysis in order to give a better picture of the actual risk for individual lakes.

\section{Appendix A}

Ordered list of the 100 lakes with highest topographic rock slide potential (TRSP).

\begin{tabular}{llll}
\hline Lake Id & Lake name & County & TRSP (scaled) \\
\hline 1994 & Eikesdalsvatnet & Møre og Romsdal & 1.000 \\
22 & Bandak & Telemark & 0.885
\end{tabular}




\begin{tabular}{|c|c|c|c|}
\hline 1800 & Breimsvatnet & Sogn og Fjordane & 0.817 \\
\hline 1864 & Suldalsvatnet & Rogaland & 0.750 \\
\hline 1806 & Lovatnet & Sogn og Fjordane & 0.579 \\
\hline 1571 & Årdalsvatnet & Sogn og Fjordane & 0.564 \\
\hline 1604 & Veitastrondvatnet & Sogn og Fjordane & 0.542 \\
\hline 1683 & Øvre Tysdalsvatnet & Rogaland & 0.534 \\
\hline 2 & Tinnsjø & Telemark & 0.500 \\
\hline 1524 & Ørsdalsvatnet & Rogaland & 0.495 \\
\hline 1734 & $\mathrm{~J} \varnothing \mathrm{lstravatnet}$ & Sogn og Fjordane & 0.474 \\
\hline 1807 & Hornindalsvatnet & Sogn og Fjordane & 0.453 \\
\hline 1889 & Ringedalsvatnet & Hordaland & 0.430 \\
\hline 1802 & Strynevatnet & Sogn og Fjordane & 0.396 \\
\hline 27288 & Oldevatnet Sør & Sogn og Fjordane & 0.348 \\
\hline 147 & Gjende & Oppland & 0.316 \\
\hline 1400 & Sirdalsvatnet & Vest-Agder & 0.298 \\
\hline 825 & Tunsbergsdalsvatnet & Sogn og Fjordane & 0.294 \\
\hline 1905 & Eidfjordvatnet & Hordaland & 0.261 \\
\hline 1274 & Fyresvatnet & Telemark & 0.250 \\
\hline 1497 & Vassbygdvatnet & Sogn og Fjordane & 0.244 \\
\hline 1067 & Botsvatn & Aust-Agder & 0.227 \\
\hline 1504 & Fretheimsdalsvatnet & Sogn og Fjordane & 0.223 \\
\hline 9 & Totak & Telemark & 0.207 \\
\hline 1451 & Øystrebøvatnet & Sogn og Fjordane & 0.198 \\
\hline 1399 & Lundevatnet & Rogaland & 0.197 \\
\hline 1279 & Folurdvatnet & Telemark & 0.197 \\
\hline 8 & Kvitseidvatnet & Telemark & 0.190 \\
\hline 1953 & Tussevatnet & Møre og Romsdal & 0.184 \\
\hline 1801 & Sanddalsvatnet & Sogn og Fjordane & 0.182 \\
\hline 2118 & Steinslandsvatnet & Hordaland & 0.176 \\
\hline 1865 & Røldalsvatnet & Hordaland & 0.175 \\
\hline 2044 & Gjønavatnet & Hordaland & 0.171 \\
\hline 1035 & Storvatnet & Nordland & 0.171 \\
\hline 1765 & Storebottvatnet & Sogn og Fjordane & 0.171 \\
\hline 723 & Salsvatnet & Nord-Trøndelag & 0.170 \\
\hline 517 & Vangsmjøsi & Oppland & 0.165 \\
\hline 1966 & Sakrisvatnet & Møre og Romsdal & 0.161 \\
\hline 2177 & Virdnejavri & Finnmark & 0.160 \\
\hline 49 & Byrtevatn & Telemark & 0.159 \\
\hline 871 & Hopvatnet & Nordland & 0.155 \\
\hline 1701 & Sandvinvatnet & Hordaland & 0.153 \\
\hline 1070 & Vatndalsvatnet & Aust-Agder & 0.152 \\
\hline 778 & Storglomvatnet & Nordland & 0.151 \\
\hline 746 & Bjørnefossvatnet & Nordland & 0.145 \\
\hline 2084 & Evangervatnet & Hordaland & 0.144 \\
\hline 24911 & Svartevatnet & Aust-Agder & 0.143 \\
\hline 810 & $\varnothing$ vrevatnet & Nordland & 0.143 \\
\hline 833 & Heggmovatnet & Nordland & 0.142 \\
\hline 64 & Bitdalsvatnet & Telemark & 0.137 \\
\hline 45489 & Trolldalsvatnet & Nordland & 0.137 \\
\hline 1681 & Tysdalsvatnet & Rogaland & 0.135 \\
\hline 2110 & Dalavatnet & Møre og Romsdal & 0.134 \\
\hline 1527 & Austrumdalsvatnet & Rogaland & 0.128 \\
\hline 872 & Storvatnet & Nordland & 0.126 \\
\hline 892 & Selbusjøen & Sør-Trøndelag & 0.126 \\
\hline 1805 & Oldevatnet Nord & Sogn og Fjordane & 0.124 \\
\hline 1212 & Trollfjordvatnet & Nordland & 0.123 \\
\hline 43961 & Arstaddalsdammen & Nordland & 0.120 \\
\hline 7 & Flåvatn & Telemark & 0.119 \\
\hline 20070 & indre Vinjavatnet & Rogaland & 0.117 \\
\hline 452 & Fjellvatnet & Nordland & 0.112 \\
\hline 22028 & Hildalsvatnet & Hordaland & 0.112 \\
\hline 1771 & Ommedalsvatnet & Sogn og Fjordane & 0.109 \\
\hline 29369 & Nigardsbrevatnet & Sogn og Fjordane & 0.104 \\
\hline
\end{tabular}

\begin{tabular}{llll}
29060 & Nedstevatnet & Møre og Romsdal & 0.104 \\
149 & Vågåvatnet & Oppland & 0.104 \\
1485 & Sandvikevatnet & Hordaland & 0.103 \\
2382 & Svartholvatnet & Troms & 0.102 \\
500 & Storvatnet & Nordland & 0.101 \\
768 & Gråatnet & Nordland & 0.099 \\
1939 & Osdalsvatnet & Møre og Romsdal & 0.097 \\
1200 & Innervatnet & Nordland & 0.095 \\
1869 & Lonavatnet & Hordaland & 0.095 \\
1951 & Raudstadvatnet & Møre og Romsdal & 0.095 \\
1214 & Solbjørnvatnet & Nordland & 0.094 \\
870 & Sildhopvatnet & Nordland & 0.093 \\
1530 & Store Myrvatnet & Rogaland & 0.093 \\
1537 & Gyavatnet & Rogaland & 0.091 \\
1063 & Byglandsfjorden & Aust-Agder & 0.091 \\
29558 & Brevatnet & Sogn og Fjordane & 0.090 \\
1528 & Maudalsvatnet & Rogaland & 0.090 \\
864 & Langvatnet & Nordland & 0.089 \\
231 & Rondvatnet & Oppland & 0.089 \\
55721 & Kipparfjordvatnet & Finnmark & 0.089 \\
1782 & Bjørndalsvatnet & Sogn og Fjordane & 0.089 \\
44049 & Spilderdalsvatnet & Nordland & 0.088 \\
2026 & Berdalsvatnet & Rogaland & 0.088 \\
2027 & Botnavatn & Rogaland & 0.087 \\
1866 & Valldalsvatnet & Hordaland & 0.086 \\
1064 & Åraksfjorden & Aust-Agder & 0.086 \\
28950 & Almdokkevatnet & Sogn og Fjordane & 0.084 \\
1786 & Risevatnet & Sogn og Fjordane & 0.083 \\
25078 & Tengedalsvatnet & Rogaland & 0.083 \\
27566 & Torsnesvatn & Hordaland & 0.082 \\
1401 & Hovsvatnet & Rogaland & 0.082 \\
770 & Silavatnet & Nordland & 0.081 \\
34180 & Dalavatnet & Møre og Romsdal & 0.080 \\
29075 & Stegholvatnet & Sogn og Fjordane & 0.080 \\
856 & Reinoksvatnet & Nordland & 0.079 \\
\hline & & & \\
\hline
\end{tabular}

Acknowledgements. The present study is part of the ICG project "20061327 - Norwegian lakes exposed to rockslides and tsunamis" funded by The Norwegian Water Resources and Energy Directorate (NVE), the International Centre for Geohazards (ICG), the Research Council of Norway and the University of Oslo. This paper is contribution 245 of the International Centre for Geohazards. The authors would like to thank Lars Harald Blikra for comments and contributions to the project. Grethe Holm Midttømme at NVE also provided valuable comments and help with data acquisition.

Edited by: A. Guenther

Reviewed by: D. J. Hutchinson and another anonymous referee

\section{References}

Carrara, A., Cardinali, M., Detti, R., Guzzetti, F., Pasqui, V., and Reichenbach, P.: Gis techniques and statistical models in evaluating landslide hazard, Earth Surf. Proc. Land., 16, 427-445, 1991.

Carrara, A. and Pike, R. J.: Gis technology and models for assessing landslide hazard and risk, Geomorphology, 94, 257-260, 2008.

Crosta, G. B. and Frattini, P.: Distributed modelling of shallow landslides triggered by intense rainfall, Nat. Hazards Earth Syst. Sci., 3, 81-93, 2003, http://www.nat-hazards-earth-syst-sci.net/3/81/2003/. 
Dade, W. B. and Huppert, H. E.: Long-runout rockfalls, Geology, 26, 803-806, 1998.

Dussauge, C., Grasso, J. R., and Helmstetter, A. S.: Statistical analysis of rockfall volume distributions: Implications for rockfall dynamics, J. Geophys. Res.-Sol. Ea., 108, 2286, doi:10.1029/2001jb000650, 2003.

Freeman, T. G.: Calculating catchment-area with divergent flow based on a regular grid, Comput. Geosci., 17, 413-422, 1991.

Fritz, H. M., Hager, W. H., and Minor, H. E.: Near field characteristics of landslide generated impulse waves, J. Waterw. Port C.-ASCE, 130, 287-302, 2004.

Furseth, A.: Skredulykker i norge, Tun Forlag, Oslo, Norway, 1st edn., 207 pp., 2006.

Guzzetti, F. and Reichenbach, P.: Towards a definition of topographic divisions for italy, Geomorphology, 11, 57-74, 1994.

Guzzetti, F., Carrara, A., Cardinali, M., and Reichenbach, P.: Landslide hazard evaluation: A review of current techniques and their application in a multi-scale study, central italy, Geomorphology, 31, 181-216, 1999.

Guzzetti, F., Crosta, G., Detti, R., and Agliardi, F.: Stone: A computer program for the three-dimensional simulation of rock-falls, Comput. Geosci., 28, 1079-1093, 2002a.

Guzzetti, F., Malamud, B. D., Turcotte, D. L., and Reichenbach, P.: Power-law correlations of landslide areas in central italy, Earth Planet. Sc. Lett., 195, 169-183, 2002 b.

Günther, A.: Slopemap: Programs for automated mapping of geometrical and kinematical properties of hard rock hill slopes, Comput. Geosci., 29, 865-875, 2003.

Harbitz, C., Harbitz, A., and Nadim, F.: On probability analysis in snow avalanche hazard zoning, Ann. Glaciol., 32, 290-298, 2001a.

Harbitz, C. B., Domaas, U., and Varlid, E.: Flodbølger etter fjellskred - sannsynlighet og faresonering i åfjorden, hyllestad. (rock slide generated tsunamis - probability and hazard zoning in åfjorden, western norway), Bergmekanikkdagen, 23 November 2001, Oslo, 2001b.

Harbitz, C. B., Løvholt, F., Pedersen, G., and Masson, D. G.: Mechanisms of tsunami generation by submarine landslides: A short review, Norw. J. Geol., 86, 255-264, 2006.

Hergarten, S.: Landslides, sandpiles, and self-organized criticality, Nat. Hazards Earth Syst. Sci., 3, 505-514, 2003, http://www.nat-hazards-earth-syst-sci.net/3/505/2003/.

Hergarten, S.: Aspects of risk assessment in power-law distributed natural hazards, Nat. Hazards Earth Syst. Sci., 4, 309-313, 2004 , http://www.nat-hazards-earth-syst-sci.net/4/309/2004/.

Hsü, K. J.: Catastrophic debris streams (sturzstroms) generated by rockfalls, Geol. Soc. Am. Bull., 86, 129-140, 1975.

Iverson, R. M., Schilling, S. P., and Vallance, J. W.: Objective delineation of lahar-inundation hazard zones, GSA Bulletin, 110, 972-984, 1998

Jaboyedoff, M. and Labiouse, V.: Preliminary assessment of rockfall hazard based on gis data, ISRM 2003 - Technology roadmap for rock mechanics, Johannesburg, South Africa, 575-578, 2003.

Jaboyedoff, M., Baillifard, F., Philippossian, F., and Rouiller, J.-D.: Assessing fracture occurrence using "weighted fracturing density": a step towards estimating rock instability hazard, Nat. Hazards Earth Syst. Sci., 4, 83-93, 2004,

http://www.nat-hazards-earth-syst-sci.net/4/83/2004/.

Keylock, C. and Domaas, U.: Evaluation of topographic models of rockfall travel distance for use in hazard applications, Arct. Antarct. Alp. Res., 31, 312-320, 1999.

Lan, H. X., Martin, C. D., and Lim, C. H.: Rockfall analyst: A gis extension for three-dimensional and spatially distributed rockfall hazard modeling, Comput. Geosci., 33, 262-279, 2007.

Legros, F.: The mobility of long-runout landslides, Eng. Geol., 63, 301-331, 2002.

Malamud, B. D., Turcotte, D. L., Guzzetti, F., and Reichenbach, P.: Landslide inventories and their statistical properties, Earth Surf. Proc. Land., 29, 687-711, 2004.

McEwen, A. S.: Mobility of large rock avalanches - evidence from valles marineris, mars, Geology, 17, 1111-1114, 1989.

Monaghan, J. J., Kos, A., and Issa, N.: Fluid motion generated by impact, J. Waterw. Port C.-ASCE, 129, 250-259, 2003.

Montgomery, D. R. and Dietrich, W. E.: A physically based model for the topographic control on shallow landsliding, Water Resour. Res., 30, 1153-1171, 1994.

NGI: Hotell og glassbjelke ved zakariasdemningen, Norwegian Geotechnical Institute, Oslo, NGI Report 20031673-1, 2004.

NGI: Fedafjorden, kvinesdal kommune - beregning av mulige fjellskred og flodbølger, (fedafjorden, kvinesdal municipality numerical simulations of potential rock slides and tsunamis), Oslo20061445-1, 2006.

NGU: Hazard evaluation of rock avalanches; the baraldsnes-oter $\varnothing y a$ area, Geological Survey of Norway (NGU), Trondheim, 33 pp., 2001.

Noda, E.: Water waves generated by landslides, J. Waterwa. Div.ASCE, 96, 835-855, 1970.

O'Callaghan, J. F. and Mark, D. M.: The extraction of drainage networks from digital elevation data, Comput. Vision Graph., 28, 323-344, 1984.

Perla, R., Lied, K., and Kristensen, K.: Particle simulation of snow avalanche motion, Cold Reg. Sci. Technol., 9, 191-202, 1984.

Quinn, P. F., Beven, K. J., and Lamb, R.: The $\ln (\mathrm{a} / \mathrm{tan}-\mathrm{beta})$ index how to calculate it and how to use it within the topmodel framework, Hydrol. Process., 9, 161-182, 1995.

Scheidegger, A.: On the prediction of the reach and velocity of catastrophic landslides, Rock Mech. Rock Eng., 5, 231-236, 1973.

Slingerland, R. L. and Voight, B.: Occurrences, properties and predictive models of landslide-generated water waves, in: Rockslides and avalanches, 2, engineering sites, edited by: Voight, B., Developments in geotechnical engineering, Elsevier Scientific Publishing Co., Amsterdam, 317-397, 1979.

Sælevik, G., Jensen, A., and Pedersen, G.: Experimental investigation of impact generated impulse waves; related to a potential rock slide, western norway, Coastal Engineering, in review, 2009.

Walder, J. S., Watts, P., Sorensen, O. E., and Janssen, K.: Tsunamis generated by subaerial mass flows, J. Geophys. Res.-Sol. Ea., 108(B5), 2236, doi:10.1029/2001JB000707, 2003.

Wiegel, R. L., Noda, E. K., Kuba, E. M., Gee, D. M., and Tornberg, G. F.: Water waves generated by landslides in reservoirs, J. Waterway Div.-ASCE, 96, 307-333, 1970.

Zweifel, A., Hager, W. H., and Minor, H. E.: Plane impulse waves in reservoirs, J. Waterw. Port C.-ASCE, 132, 358-368, 2006. 